\title{
Reproductive Evaluation of Charolais and Charbray Bulls on the Reproductive Efficiency of Herds in Warm Sub-Humid Climate of Veracruz
}

\author{
Torres-Aburto, Víctor Fernando ${ }^{1}$; Hernández-Beltrán, Antonio ${ }^{1}$; Cervantes-Acosta, Patricia ${ }^{1}$; \\ Barrientos-Morales, Manuel ${ }^{1}$; Arrieta-González, Armando, Rodríguez-Andrade, Araceli ${ }^{2}$; \\ Hernández-Flores, Herminio ${ }^{3}$; Domínguez-Mancera, Belisario ${ }^{1^{*}}$ \\ ${ }^{1}$ Universidad Veracruzana. Facultad de Medicina Veterinaria y Zootecnia. Veracruz, Veracruz, México, C. P. \\ 91710. \\ 2 InstitutoTecnológico Nacional de México / Campus Instituto Tecnológico de Veracruz. Veracruz, Veracruz, \\ México, C.P. 91897. \\ *Corresponding author: beldominguez@uv.mx
}

\begin{abstract}
Objective: To correlate the Breeding Soundness Evaluation (BSE) of Charolais and Charbray bulls in the warm sub-humid climate and its effect on the pregnancy rate and calving interval of herds to estimate differences between breeds.

Design/Methodology/Approach: BSE was carried out on N=90 Bulls, Charolais $(n=33)$ and Charbray $(n=57)$, evaluated in situ during the period of 2017 to 2019. Variables for the bull (age, body condition, libido, and scrotal circumference), semen (concentration, motility, and volume), herd (pregnancy rate and calving interval), and environment (rainy and dry season) were analyzed with the one-way ANOVA, Factorial, Multiple regression and Multivariate analysis.

Results: Charolais and Charbray bulls show similar results in the BSE ( $p>0.05)$ in a warm sub-humid climate. Study Limitations/Implications: Yearly seasons (rainy or dry) do not affect $(p<0.05)$ the BSE rating. Libido is associated $(p<0.05)$ with age $(R=-0.42)$, sperm motility $(R=0.67)$, sperm concentration $(R=0.66)$ and pregnancy rate $(\mathrm{R}=0.63)$.

Findings/Conclusions: Variables with high association $(\mathrm{p}<0.05)$ with pregnancy rate were libido $(\mathrm{R}=0.63)$, motility $(R=0.60)$, sperm concentration $(R=0.51)$ and age $(R=-0.50)$; variables with high association $(p<0.05)$ with calving interval were: age $(R=0.74)$ and libido $(R=-0.33)$. Charolais and Charbray bulls show similar reproductive efficiency in herds under a warm sub-humid climate in Veracruz.
\end{abstract}

Key words: Charolais bulls, Charbray bulls, herd, efficiency.

Citation: Torres-Aburto, V.F., HernándezBeltrán A., Cervantes-Acosta P., Barrientos-Morales M., Arrieta-González A., Rodríguez-Andrade A., HernándezFlores H., Domínguez-Mancera B. (2021). Reproductive evaluation of Charolais and Charbray bulls on the reproductive efficiency of herds in the humid tropics of Veracruz. Agro Productividad, 14(\#). https://doi.org/10.32854/agrop.v14i6.1936

Editor in Chief: Dr. Jorge Cadena Iñiguez

Estimated publication date: July 2021

This work is licensed under a Creative Commons Attribution-NonCommercial 4.0 International license

\section{INTRODUCTION}

An increase in demand for animal protein has resulted in producers on livestock farms including in their reproductive programs purebred bulls and their crosses with genetic traits specialized for meat production (Sitienei et al., 2018). The Charolais breed is a viable alternative to obtain a greater amount of kilograms per animal, due to its large corpulence, additional weight gain at weaning, and peripheral fat (Gagaoua et al., 2018). However, purebred bulls introduced to hot humid climate present difficulties in adapting to environmental conditions in the area, which has a high temperaturehumidity index (THI), low availability of forage and water, and this condition causes the animals to be subjected to prolonged periods of heat stress during puberty and sexual maturity (Rahman et al., 2018). In order to reduce the negative effects related to climatic variables, it has been decided to carry out genetic crosses with Bos indicus, specifically with Brahman, resulting in the synthetic Charbray breed (5/8 Charolais 
and 3/8 Zebu), which shows resistance to high temperatures and humidity, in addition to conserving the characteristics of a meat breed. Under tropical conditions, where there is high environmental temperature and/or humidity, cattle reproduction can be impacted by heat stress (Morrell, 2020). With the above and as consequence of the climatic variability present in tropical zones in recent decades (Dominguez-Mancera, 2017), it was proposed to conduct evaluations of the reproductive capacity of Charolais and Charbray bulls to determine the differences in reproductive performance between breeds on the reproductive efficiency of the herd.

\section{METHODS AND MATERIALS}

\section{Experimental animals and semen collection}

All handling, immobilization and semen collection procedures performed on bulls within the Livestock Production Units (LPU) by the veterinary services and they were evaluated and approved by the Bioethics Committee of the FMVZ-UV (COBIBA010/2017). Information from the breeding soundness evaluation (BSE) of bulls ( $N=90$; Charolais $n=33$, Charbray $n=57$ ), carried out by the Animal Reproductive Biology Laboratory and the Cell Biology Laboratory of FMVZ-UV, was used. All the bulls were under an extensive grazing system with Cynodon nlemfuensis and Brachiaria humidicola grasses, ranging in age from 1 to 11 years, with no apparent health deterioration at the time of the BSE. The cows used ( $N=2274)$ to measure the reproductive performance of bulls in herds were clinically healthy and fertile at the time the BSE was performed; cows with reproductive abnormalities were excluded from the analysis. Transrectal palpation and ultrasonography of the reproductive tract were performed for gestation detection using a 6.5 MHz linear Minitube probe (Minitube, Verona, WI, USA). In addition, reproductive records from the herd $(\mathrm{N}=42)$ were used.

\section{Breeding Soundness Evaluation; Semen evaluation}

Semen samples were collected from January 2017 through December 2019, each of these were evaluated in situ immediately after collection ( 5 minutes). Semen was collected in a test tube with a graduation of 1 to $15 \mathrm{ml}$ and volume, color and density were measured (Chenoweth, 1983). Electroejaculation was performed on the bulls with a three-electrode probe (Minitube, Verona, WI, USA; $\varnothing: 2 " / 5.08 \mathrm{~cm}$; length: $33 \mathrm{~cm}$ ). Individual motility was assessed in a sample diluted with warm saline. A drop of diluted semen was placed on a slide on a thermoplate at $37^{\circ} \mathrm{C}$, covered with a coverslip and examined at 40X. The proportion of sperm moving progressively through the field of view was estimated by finding multiple groups of 10 sperm and counting how many sperm are progressive versus how many are not (Ibanescu et al., 2020). The spectrophotometric method was used to measure sperm concentration $\left(\mathrm{x}^{6} \mathrm{6} / \mathrm{mL}\right)$. Once the sample was obtained, a drop of undiluted semen was taken and placed in the Microcube for SDM-1 (Minitube, Verona, WI, USA) with a capacity of $2 \mu \mathrm{L}$, then inserted into the spectrophotometer model SDM-1 (Minitube) calibrated for cattle (Bompart et al., 2019). To evaluate bull libido, the test was conducted in a small pen where the bull 
and a cow showing signs of estrus could be easily observed; the bull was allowed to be in contact with the cow exhibiting behavioral estrus for a period of 5 minutes; libido was scored (1-10 scale) with the system proposed by Chenoweth et al. (2010).

\section{Analysis and collection of climatological data}

Climatological data (2017-2019) from the meteorological station located in the municipality of Juan Rodriguez Clara, Veracruz (30143), were used, provided by the National Meteorological Service's Gulf of Mexico forecast center, zone where the herds and bulls analyzed are located. With climatological data, the climatic safety index for livestock, known as the temperature-humidity index (THI), was obtained with the following equation: $T H I=1.8+T+32-\left(0.55-0.55^{*} H R\right)^{*}\left(1.8^{*} T-26\right)$ (Eq. 1). Where: "T" is the average daily temperature in ${ }^{\circ} \mathrm{C}$ and $\mathrm{RH}$ is the percentage (\%) of relative humidity. Nienaber and Hahn (2007) have considered four categories of THI to evaluate environmental and thermal conditions and their associated impact on breathing per minute. THI values $\leq 74$ were considered as Comfort; 75-78 as Alert; 7983 as Danger and $\geq 84$ as Emergency. In addition to THI, the climatic variables analyzed were: accumulated monthly precipitation $(\mathrm{mm})$, dominant wind speed $(\mathrm{m} / \mathrm{s})$, daily temperature $\left({ }^{\circ} \mathrm{C}\right.$ ) and relative humidity (\%). With the climatological data, two seasons of the year were recorded (rainy and dry).

\section{Statistical Analysis}

The statistical package STATISTICA V10 (StatSoft, 2011) was used for all statistical analyses and the figures were edited with the help of Sigma Plot V11 software (2008). The Shapiro-Wilk test was used to test for normality and Bartlett's test for homoscedasticity. One-way and factorial ANDEVA (GLM) was performed to evaluate main and pooled effects; multiple comparisons by Tukey $(p<0.05)$. Simple linear regression was performed with the model: $Y_{i}=\alpha+\beta^{\star} X+\varepsilon_{i}$ (Eq. 2) where "Y" is the dependent variable and " $X$ " is the independent variable. 1) Dependent variables: sperm concentration, individual motility, libido, gestation rate, inter-calving interval. 2) Independent variables: bull and semen characteristics. Multiple linear regression analysis was used to obtain statistical models that best explained herd efficiency. Lastly, exploratorymultivariate analyses (Cluster, Correspondence and Principal Component Analyses) were performed to obtain the variables and total variation of the model that best describes the BSE of the bull on the reproductive efficiency of the herd.

\section{RESULTS}

\section{Descriptive analysis of BSE of Charolais and Charbray bulls}

Table 1 shows the values of the minimum-quadratic means and standard errors for each variable of the BSE of Charolais and Charbray bulls where it can be seen that there is no difference ( $p>0.05)$ between breeds; in addition, the reproductive efficiency of the herds with the two breeds is not different ( $p>0.05)$. 
Table 1. Bull Breeding Soundness Evaluation descriptive análisis of the Charolais and Charbray bulls in warm subhumid climate of Veracruz.

\begin{tabular}{c|l|c|c}
\multicolumn{2}{c|}{ Bull Breeding Soundness Evaluation } & \multicolumn{2}{c}{ Bull breed } \\
\hline Experimental Unit & \multicolumn{1}{|c}{ Parameter } & Charolais (n=33) & Charbay (n=57) \\
\hline \multirow{4}{*}{ Bull } & Body Condition Score (scale 1-5) & $2.80 \pm 0.06$ & $2.85 \pm 0.04$ \\
\cline { 2 - 4 } & Age (years) & $5.09 \pm 0.37$ & $5.00 \pm 0.37$ \\
\cline { 2 - 4 } & libido (scale 1-10) & $7.81 \pm 0.21$ & $7.56 \pm 0.17$ \\
\cline { 2 - 4 } & Scrotal circumference (cm) & $36.60 \pm 0.30$ & $36.87 \pm 0.23$ \\
\cline { 2 - 4 } & Semen volume (mL) & $3.63 \pm 0.16$ & $3.53 \pm 0.18$ \\
\cline { 2 - 4 } & Sperm concentration (X106) & $649.45 \pm 52.76$ & $621.42 \pm 50.64$ \\
\cline { 2 - 4 } & Sperm motility (\%) & $52.78 \pm 3.15$ & $68.84 \pm 2.89$ \\
\hline \multirow{4}{*}{ Herd } & Pregnancy rate (\%) & $697.75 \pm 13.37$ & $681.73 \pm 16.42$ \\
\cline { 2 - 4 } & Calving interval (days) & $33.25 \pm 0.49$ & $28.80 \pm 0.71$ \\
\cline { 2 - 4 } & Cow / Bull ratio (n) & & \\
\hline
\end{tabular}

Note: Bulls with 1 and 2 years old do not report data on pregnacy rate and calves interval.

\section{Climatological analysis}

With the meteorological data, it was decided to perform a climatological analysis of the area, the results of which are shown in Figure 1.

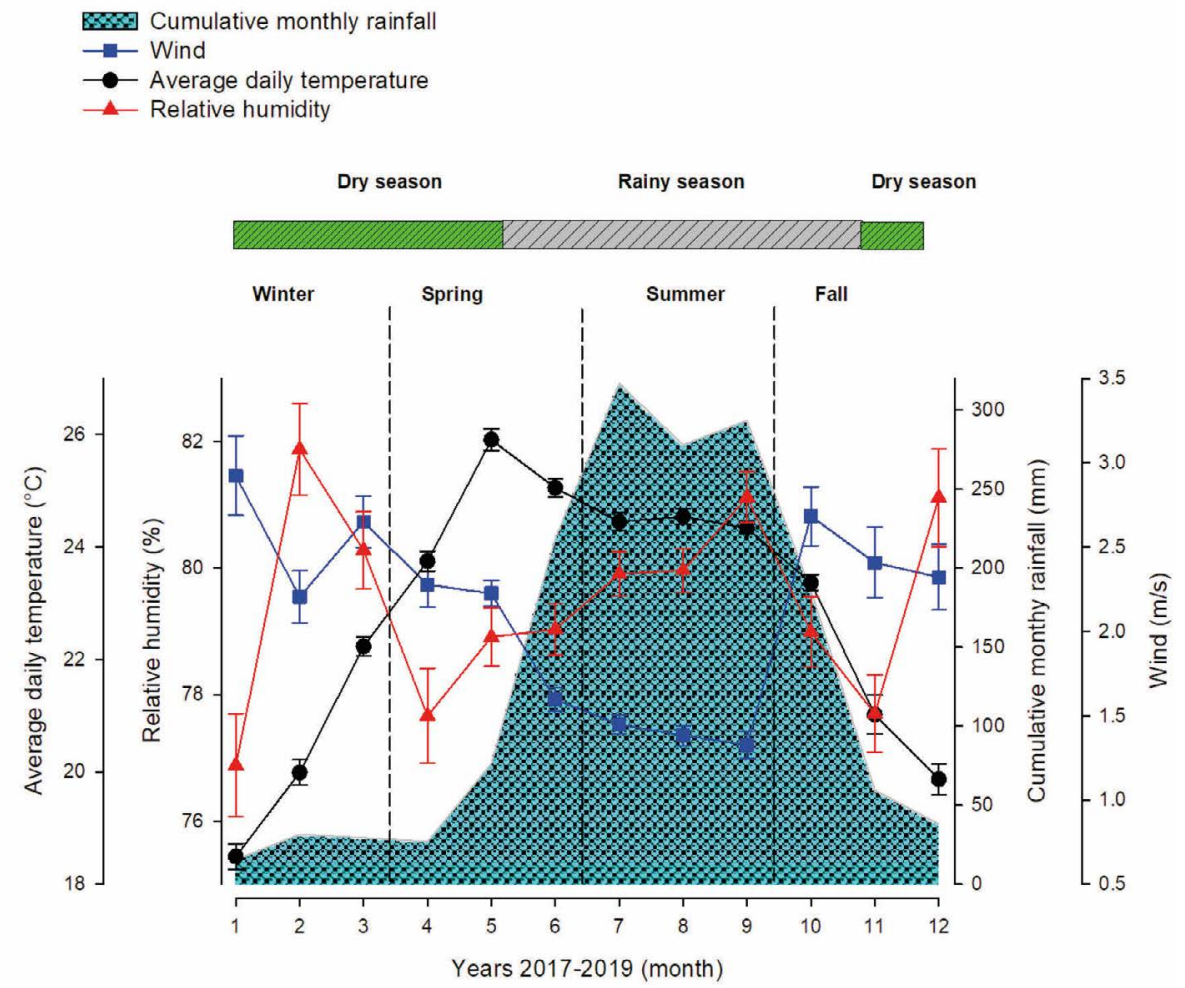

Figure 1. Monthly analysis (mean \pm ee) of the climatic variables in warm subhumid climate of Veracruz. Cumulative monthly rainfall ( $\mathrm{mm}$, shaded area). Dominant wind speed ( $\mathrm{m} / \mathrm{s}$, blue box), average daily temperature $\left({ }^{\circ} \mathrm{C}\right.$, black circle), relative humidity (\%, red triangle). The vertical dotted lines indicate the change of season in the year. The horizontal bars show the two main seasons of the year in the region: Rainy season (gray) and Dry season (green). 
With the combined values of temperature $\left({ }^{\circ} \mathrm{C}\right)$ and humidity $(\%)$, the THI was obtained and with this, the periods and seasons of the year when there could be heat stress could occur and affect the reproductive capacity of Charolais and Charbray bulls were determined (Figure 2).

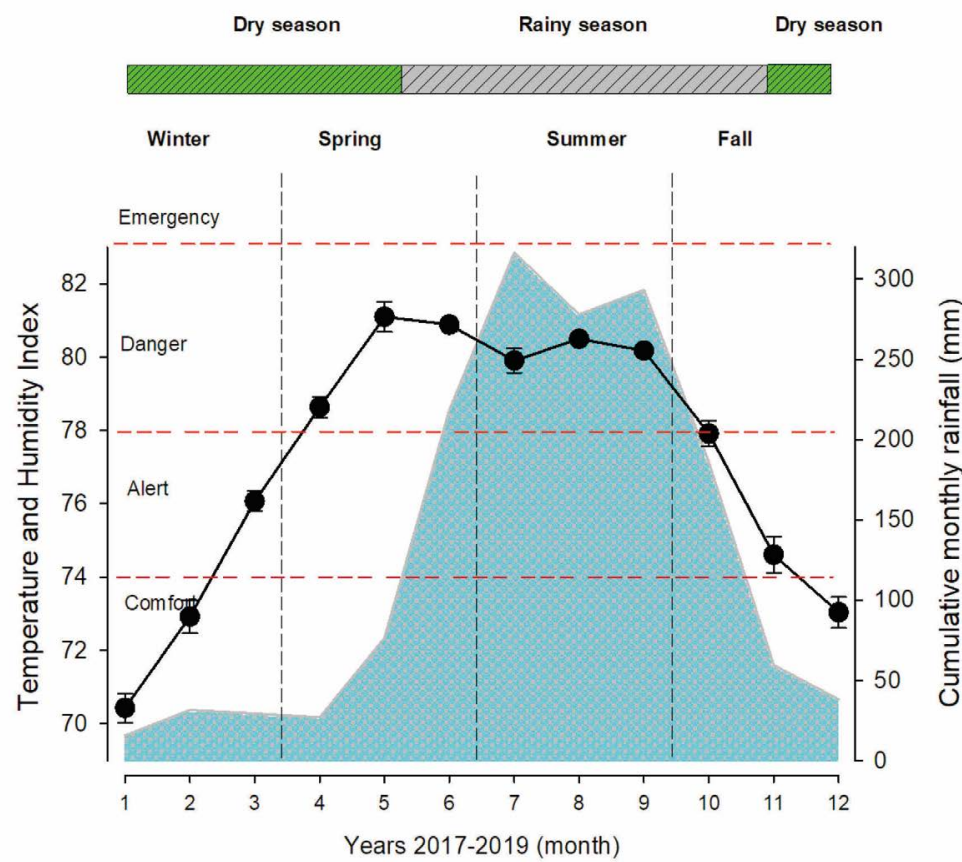

Figure 2. Monthly analysis (mean \pm ee) of the Temperature and Humidity Index (THI) in warm subhumid climate of Veracruz. Cumulative monthly rainfall ( $\mathrm{mm}$, shaded area). Temperature and humidity index (THI, black circle), The vertical dotted lines indicate the change of season in the year. The horizontal bars show the two main seasons of the year in the region: Rainy season (gray) and Dry season (green).

\section{Effect of time of year on BSE of Charolais and Charbray bulls}

Table 2 shows the effect of the main seasons of the year (rainy and dry) on semen parameters and bull behavior (libido); it can be observed that there are no differences ( $p>0.05)$, both breeds behave similarly in the parameters of semen and libido.

\section{Correlation of the BSE of bulls with herd efficiency}

Table 3 shows the results from the correlation analysis on herd efficiency (pregnancy rate and calving interval). 
Table 2. Analysis of the main seasons of the year on the parameters of the semen of Charolais and Charbray bulls in warm subhumid climate of Veracruz.

\begin{tabular}{l|c|c|c|c}
\hline \multirow{2}{*}{ Semen evaluation } & \multicolumn{4}{|c}{ Season } \\
\cline { 2 - 5 } & \multicolumn{2}{|c}{ Rainy } & \multicolumn{2}{c}{ Dry } \\
\cline { 2 - 5 } & $\begin{array}{c}\text { Charolais } \\
(\mathbf{n}=\mathbf{1 1})\end{array}$ & $\begin{array}{c}\text { Charbray } \\
(\mathbf{n}=\mathbf{1 9 )}\end{array}$ & $\begin{array}{c}\text { Charolais } \\
(\mathbf{n}=\mathbf{2 2})\end{array}$ & $\begin{array}{c}\text { Charbray } \\
(\mathbf{n}=\mathbf{3 8})\end{array}$ \\
\hline Volume $(\mathrm{mL})$ & $3.50 \pm 0.21$ & $3.71 \pm 0.30$ & $3.70 \pm 0.22$ & $3.48 \pm 0.22$ \\
\hline Concentration $\left(\mathrm{X} 10^{6}\right)$ & $658.54 \pm 96.77$ & $536.68 \pm 91.74$ & $644.90 \pm 64.27$ & $663.78 \pm 60.25$ \\
\hline Sperm motility $(\%)$ & $71.72 \pm 5.85$ & $63.47 \pm 5.50$ & $73.27 \pm 3.81$ & $71.52 \pm 3.32$ \\
\hline libido $(1-10)$ & $7.90 \pm 0.31$ & $7.57 \pm 0.36$ & $7.77 \pm 0.29$ & $7.55 \pm 0.18$ \\
\hline
\end{tabular}

Note: no significant differences ( $p>0.05$ ) are reported between bulls and between seasons.

Table 3. Bull Breeding Soundness Evaluation correlation analysis on herd parameters: Pregnancy rate and Calving interval.

\begin{tabular}{|c|c|c|c|c|c|c|c|c|c|}
\hline \multirow{2}{*}{$\begin{array}{c}\text { Herd } \\
\text { efficiency }\end{array}$} & \multirow{2}{*}{$\begin{array}{l}\text { Breeding Soundness } \\
\text { Evaluation }\end{array}$} & \multicolumn{8}{|c|}{ Simple linear correlation $\mathbf{Y}=\mathbf{a}+\mathbf{b}^{*} \mathbf{X}$} \\
\hline & & $\mathbf{R}$ & $\mathbf{R}^{2}$ & $\begin{array}{c}\text { Intercept } \\
\text { (a) }\end{array}$ & ee (a) & $\begin{array}{c}\text { Value of } \\
\text { "p" }\end{array}$ & slope (b) & ee (b) & $\begin{array}{c}\text { Value of } \\
\text { "p" }\end{array}$ \\
\hline \multirow{7}{*}{$\begin{array}{l}\text { Pregnancy } \\
\text { rate }\end{array}$} & Age (years) & -0.498 & 0.248 & 62.509 & 2.959 & 0.001 & -2.329 & 0.478 & 0.001 \\
\hline & Body condition score (1-5) & 0.069 & 0.005 & 43.521 & 9.522 & 0.001 & 1.960 & 3.335 & 0.558 \\
\hline & Scrotal circumference $(\mathrm{cm})$ & 0.089 & 0.008 & 29.292 & 26.143 & 0.266 & 0.537 & 0.709 & 0.451 \\
\hline & Volume (mL) & 0.010 & 0.057 & 48.776 & 3.790 & 0.001 & 0.081 & 0.985 & 0.934 \\
\hline & Sperm motility (\%) & 0.642 & 0.412 & 23.829 & 3.678 & 0.001 & 0.350 & 0.049 & 0.001 \\
\hline & Concentration $\left(\mathrm{X} 10^{6}\right)$ & 0.538 & 0.279 & 37.928 & 2.308 & 0.001 & 0.017 & 0.003 & 0.001 \\
\hline & Libido (scale 1-10) & 0.640 & 0.409 & 10.051 & 5.605 & 0.077 & 5.120 & 0.725 & 0.001 \\
\hline \multirow{7}{*}{$\begin{array}{l}\text { Calving } \\
\text { interval }\end{array}$} & Age (years) & 0.745 & 0.554 & 509.810 & 20.280 & 0.001 & 30.996 & 3.275 & 0.001 \\
\hline & Body condition score (1-5) & -0.144 & 0.007 & 791.624 & 84.091 & 0.001 & -36.369 & 29.452 & 0.220 \\
\hline & Scrotal circumference $(\mathrm{cm})$ & 0.009 & 0.025 & 670.159 & 233.669 & 0.005 & 0.503 & 6.341 & 0.938 \\
\hline & Volume (mL) & -0.195 & 0.038 & 741.394 & 33.098 & 0.001 & -14.506 & 8.606 & 0.968 \\
\hline & Sperm motility $(\%)$ & -0.305 & 0.081 & 795.586 & 40.664 & 0.001 & -1.483 & 0.545 & 0.008 \\
\hline & Concentration $\left(\mathrm{X} 10^{6}\right)$ & 0.264 & 0.070 & 737.325 & 23.512 & 0.001 & -0.075 & 0.032 & 0.023 \\
\hline & Libido (scale 1-10) & -0.349 & 0.110 & 878.385 & 60.838 & 0.001 & -24.893 & 7.867 & 0.002 \\
\hline
\end{tabular}

Note: $\mathrm{R}=$ correlation coefficient; $\mathrm{R}^{2}=$ coefficient of determination; $\mathrm{a}$ : Intercept; b: slope; ee=standard error; "p" value: probability significance value.

\section{Evaluation of BSE on herd parameters}

The main effects and their interactions of pregnancy rate and calving internal with the variables that best explain BSE (age) and bull behavior (libido) were analyzed (Figure 3). The libido of Charolais and Charbray bulls decreases with age $(\mathrm{p}<0.05)$ (Figure 3a). Thin bulls (CC 3 ) and obese bulls (CC 5) show low libido $(\mathrm{p}<0.05)$ Figure 3b. Sperm motility and concentration decrease with the bull's age $(p<0.05)$ (Figure 3c). High libido values are associated with high sperm motility and concentration $(p<0.05)$ (Figure 3d). The herd's reproductive parameters are affected by libido (Figure 3e) and age (Figure 3f) of the bull. 

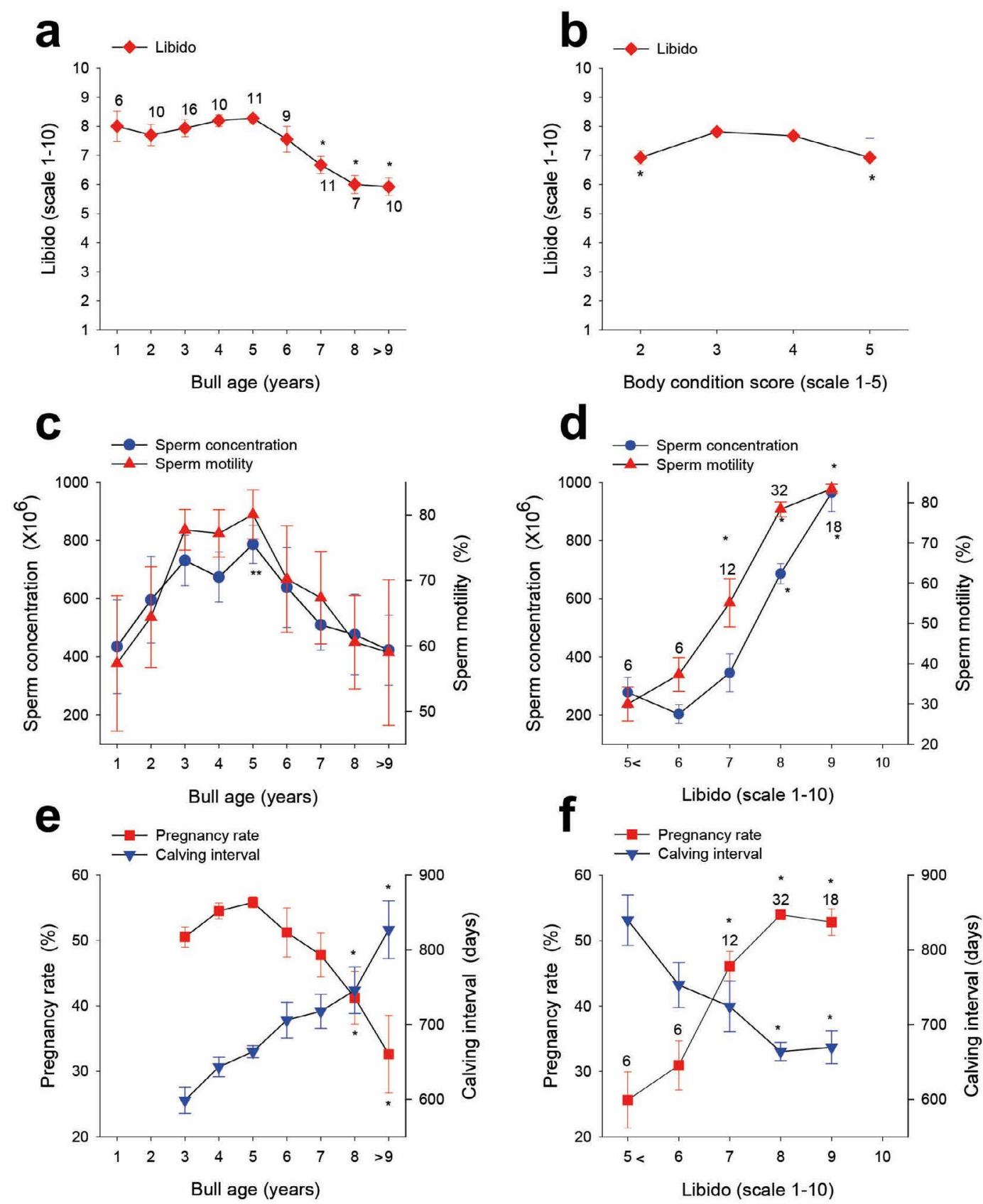

Figure 3. Analysis of main effects of Bull Breeding Soundness Evaluation in Charolais and Charbary bulls (age, body condition and libido) on sperm concentration and sperm motility, as well as herd efficiency: pregnancy rate and calving interval. a. Bull libido at different ages: dashed line shows the average libido. b. Body condition score on bull libido: blue dashed line shows average libido. c. Sperm concentration (left) and Sperm motility (right) in bulls of different ages (years). d. Sperm concentration (left) and sperm motility (right) in bulls with different libido values. (e, f) Herd reproductive parameters, pregnancy rate (left) and calving interval (right) in bulls of different ages (e) and libido value (f). Numbers above the error bar show the number of bulls analyzed. (*) Indicates significant statistical differences $(p<0.05) .1$ and 2 year old bulls, no data on pregnancy rate shown. No bulls with a libido 10 vale are reported. 


\section{Multivariate analysis of the BSE of Charolais and Charbray bulls on herd reproductive efficiency}

Multiple regression (Forward Methodology) was performed with Libido as response variable, since it was found to be associated with BSE variables; the model obtained was: $Y_{i}=\alpha+\beta_{1} X_{1}+\beta_{2} X_{2}+\beta_{3} X_{3}+\varepsilon_{i}$ (Eq. 3). Where: $Y=$ Libido (scale 1-10), $\alpha=$ intercept (0.9749 \pm 2.71$), \beta_{1}=(-0.175 \pm 0.047), X_{1}=$ Age (1-11 years), $\beta_{2}=(0.845 \pm 0.336), X_{2}=$ Body condition (scale 1-5), $\beta_{3}=(0.140 \pm 0.070), X_{3}=\operatorname{Scrotal}$ circumference (cm), $\varepsilon=\operatorname{error}(1.15)$, $\mathrm{R}=0.469$, adjusted $\mathrm{R}^{2}=0.193$ ( $\mathrm{p}<0.05$ ); (Figure $4 \mathrm{a}$ and $4 \mathrm{~b}$ ). The pregnancy rate was the variable best associated with BSE, the multiple regression model obtained was as follows: $Y_{i}=\alpha+\beta_{1} X_{1}+\beta_{2} X_{2}+\beta_{3} X_{3}+\beta_{4} X_{4}+\varepsilon_{i}$ (Eq.4). Where: $\mathrm{Y}=$ Pregnancy rate (\%), $\alpha=$ intercept (22.745 \pm 7.89$), \beta_{1}=(-1.116 \pm 0.432), X_{1}=$ Age (1 to 11 years), $\beta_{2}=(2.450 \pm 0.972), X_{2}=$ Libido (scale 1-10), $\beta_{3}=(0.206 \pm 0.083), X_{3}=$ Sperm motility (\%), $\beta_{4}=(-0.001 \pm 0.004), X_{4}=$ Sperm concentration $\left(\mathrm{X} 10^{6}\right), \varepsilon=\operatorname{error}(7.39), \mathrm{R}=0.733$, adjusted $\mathrm{R}^{2}=0.510(\mathrm{p}<0.05)$; (Figure $4 \mathrm{c}$ and $4 d)$.

Finally, a multivariate analysis was performed, and Figure 5 a shows how the variables individual motility and sperm concentration are linked to the libido variable, and these variables that describe the reproductive capacity of the bull are associated with the pregnancy rate. It is worth mentioning that the bull's age is associated with the calving interval. By means of a correspondence analysis (Figure 5b) the dimensions (degree of inertia, variation) on herd efficiency (pregnancy rate and calving interval) were plotted with bull characteristics (libido, body condition and age); semen variables (concentration and motility) show lower degree of inertia (association), remoteness.

Finally, the principal components analysis shows the degree of association and the direction of the vectors (variables) by plotting components 1 vs 2 (Figure 5c) and components 1 vs 3 (Figure $5 d$ ). Figure 5 c shows that the gestation rate has association with libido, motility and sperm concentration; body condition is associated with season of the year; bull age shows association with inter-calving interval; bull breed is not associated with any variable; they are equal. Figure $5 \mathrm{c}$ shows similar results of Figure 5b as components 1 vs 3 are plotted.

The climatology of the zone analyzed shows significant variations throughout the year, which can influence the reproductive performance of domestic species; two predominant constants are high temperature and relative humidity, which, when combined, cause the animals to lose the ability to dissipate the heat they produce, causing heat stress (Hansen, 2009). High values of temperature and humidity are observed in the rainy season, and with increased rainfall there is biomass available for bulls in extensive systems (Casagrande et al. 2018). The semen variables of Charolais and Charbray bulls analyzed under these environmental conditions show values similar to those reported by other researchers (Torres-Aburto et al., 2020a), without marked seasonal modifications; thus showing that the Charolais breed and its crosses have adapted to the climate of the area. Dance et al. (2015) and Bourgon et al. (2018) describe a positive relationship between the quality of the pasture produced at different times of the year and the sperm concentration; in this sense, the breeds analyzed are similar 
between seasons, where differences in the quantity and quality of biomass available for grazing are marked (Cruz-Hernández et al., 2017). Bulls of European origin show a lower reproductive performance than Zebu bulls and their crosses in a warm subhumid environment (Jiménez-Severiano, 2002); in the results obtained, there were no differences in libido between the two breeds; they have adapted to the warm subhumid environment. Bull libido involves two components: (1) its ability to identify females in estrus and (2) its ability to mount them; apparently, libido is not related to semen quality or to scrotal circumference; therefore, it is possible to obtain an excellent semen sample in bulls with low libido (Galina et al., 2007), which is why it is important to include it in the BSE. Age plays a decisive role in BSE; libido, sperm concentration and motility show high values in young and mature animals, as can be seen in the results. Khan et al. (2018) report a decrease in reproductive ability as the animal ages. Regardless of the breed analyzed, once sexual maturity is reached (3 years), the indicators are stabilized for a period of 2 years and then decrease as the bull ages, causing a decrease in the reproductive efficiency of the herd (da Silva et al., 2020). Bulls aged 3 to 5 years show better performance in extensive systems on herd reproductive parameters than bulls older than 5 years, demonstrating that bulls have a useful life in extensive systems regardless of their breed (Byrne et al., 2018).

a

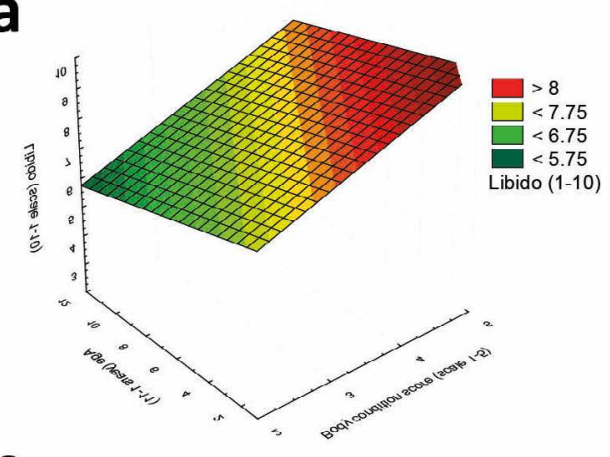

C

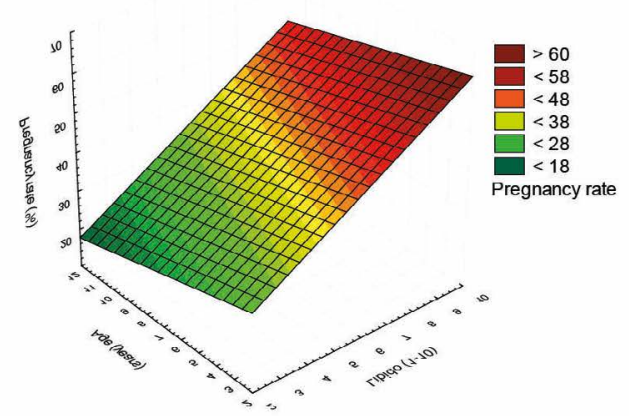

b

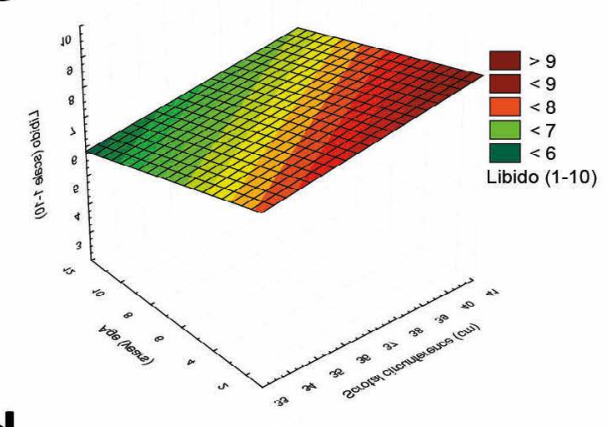

d

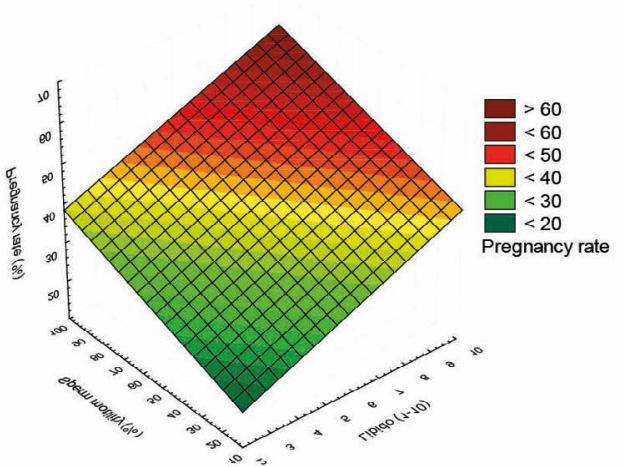

Figure 4. Multiple correlation analysis of BBSE on the variables Libido and Pregnancy rate. a. Relationship between libido scale, body condition score and bull's age. b. Relationship between libido scale, scrotal circumference and bull's age. c. Relationship between pregnancy rate, age and libido scale. d. Relationship between pregnancy rate, libido scale and sperm motility. The intensity of the color indicates an increase in the dependent variables (libido and pregnancy rate). 

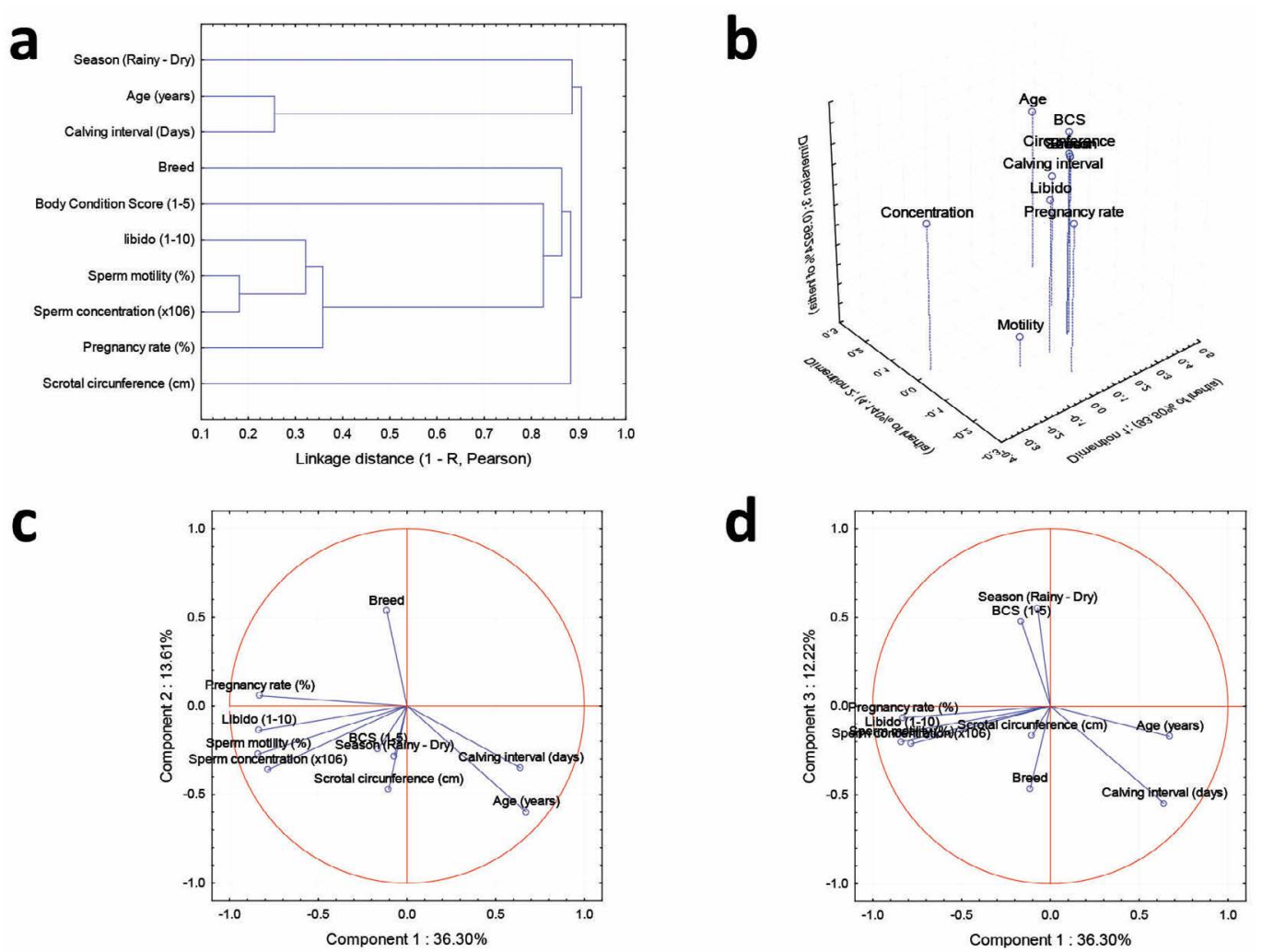

Figure 5. Multivariate analysis of BBSE of Charolais and Charbray bulls on herd efficiency. a. Clustering analysis of the BBSE and herd efficiency variables, the linkage distance was Pearson's 1-R. b. Correspondence Analysis, the dimensions that best explain the association between variables (Inertia, variability) are plotted in 3D. c. Principal components analysis of BBSE and herd efficiency, Components 1 vs 2 are plotted (Total variability 49.91\%). d. Principal components analysis of BBSE and herd efficiency, components 1 vs 3 are plotted (Total variability 48.52\%).

Although libido evaluation and mating ability are not sufficient to predict reproductive success, it is prudent to use bulls that passed all stages of BSE, including libido (Menegassi et al., 2015). Lastly, multivariate analyses have been used in the breeding soundness evaluation of bulls with the aim of defining a degree of reliability higher than 95\% for its inclusion and permanence in the herd; likewise, the effects of breed, age, season, on the sperm variables (Felton-Taylor et al., 2020) have been analyzed, and this type of analysis allows associating intrinsic (inherent to the bull) and extrinsic (management, nutrition, environment) factors that can affect the reproductive performance of the bull, and with it, explaining the effects as a whole that simple analyses cannot determine. The best association of the inter-calving interval with BSE variables was found with age; as the animal ages, the number of open days increases, where the reproductive performance of the herd presents a negative correlation in relation to the age of the bulls and cows, which leads to a negative effect on the profitability of the livestock production unit in extensive systems (Torres-Aburto et al., 2020b). 


\section{CONCLUSIONS}

Charolais and Charbray bulls show similar reproductive efficiency in herds under the hot sub-humid climate of Veracruz.

\section{REFERENCIAS}

Bompart, D., Vázquez, R.F., Gómez, R., Valverde, A., Roldán, E.R.S., García-Molina, A., \& Soler, C. (2019). Combined effects of type and depth of counting chamber, and rate of image frame capture, on bull sperm motility and kinematics. Animal Reproduction Science, 209, 106169. doi.org/10.1016/j.anireprosci.2019.106169

Bourgon, S. L., Diel de Amorim, M., Chenier, T., Sargolzaei, M., Miller, S. P., Martell, J. E., \& Montanholi, Y. R. (2018). Relationships of nutritional plane and feed efficiency with sexual development and fertility related measures in young beef bulls. Animal reproduction science, 198, 99-111. doi.org/10.1016/j.anireprosci.2018.09.007

Byrne, C.J., Fair, S., English, A.M., Urh, C., Sauerwein, H., Crowe, M.A., Kenny, D.A. (2018). Plane of nutrition before and after 6 months of age in Holstein-Friesian bulls: II. Effects on metabolic and reproductive endocrinology and identification of physiological markers of puberty and sexual maturation. Journal of Dairy Science, 101(4), pp.3460-3475. doi.org/10.3168/ jds.2017-13720

Casagrande, E., Recanati, F., \& Melià, P. (2018). Assessing the Influence of Vegetation on the Water Budget of Tropical Areas. IFAC-PapersOnLine, 51(5), pp.1-6. doi.org/10.1016/j.ifacol.2018.06.190

Chenoweth, P.J. (1983). Sexual Behavior of the Bull: A Review. Journal of Dairy Science, 66(1), pp.173-179. doi.org/10.3168/jds. S0022-0302(83)81770-6

Chenoweth, P.J., Hopkins, F.M., Spitzer, J.C., \& Larsen, R.E. (2010). Guidelines for using the bull breeding soundness evaluation form. Clinical Theriogenology, 2(1), pp.43-50.

Cruz-Hernández, A., Hernández Garay, A., Chay Canul, A. J., Mendoza Pedroza, S. I., Ramírez Vera, S., Rojas García, A. R., \& Ventura Ríos, J. (2017). Componentes del rendimiento y valor nutritivo de Brachiaria humidicola cv Chetumal a diferentes estrategias de pastoreo. Revista mexicana de ciencias agrícolas, 8(3), pp.599-610. doi.org/10.29312/remexca.v8i3.34

Dance, A., Thundathil, J., Wilde, R., Blondin, P., \& Kastelic, J. (2015). Enhanced early-life nutrition promotes hormone production and reproductive development in Holstein bulls. Journal of dairy science, 98(2), pp.987-998. doi.org/10.3168/ jds.2014-8564

da Silva Neto, J.B., Peripolli, E., da Costa e Silva, E.V., Espigolan, R., Neira, J.D.R., Schettini, G., Baldi, F. (2020). Genetic correlation estimates between age at puberty and growth, reproductive, and carcass traits in young Nelore bulls. Livestock Science, 241, 104266. doi.org/10.1016/j.livsci.2020.104266

Domínguez-Mancera, B., Hernández-Beltrán, A., Rodríguez-Andrade, A., Cervantes-Acosta, P., Barrientos-Morales, M., \& Pinos-Rodriguez, J. M. (2017). Changes in Livestock Weather Security Index (Temperature Humidity Index, THI) During the Period 1917-2016 in Veracruz, Mexico. Journal of Animal Research, 7(6), pp. 983-991. doi.org/10.5958/2277940X.2017.00149.8

Felton-Taylor, J., Prosser, K.A., Hernandez-Medrano, J.H., Gentili, S., Copping, K.J., Macrossan, P.E., \& Perry, V.E. (2020). Effect of breed, age, season and region on sperm morphology in 11,387 bulls submitted to breeding soundness evaluation in Australia. Theriogenology, 142, pp.1-7. doi.org/10.1016/j.theriogenology.2019.09.001

Gagaoua, M., Bonnet, M., De Koning, L., \& Picard, B. (2018). Reverse Phase Protein array for the quantification and validation of protein biomarkers of beef qualities: The case of meat color from Charolais breed. Meat Science, 145, pp.308-319. doi. org/10.1016/j.meatsci.2018.06.039

Galina, C.S., Horn, M.M., \& Molina, R. (2007). Reproductive behaviour in bulls raised under tropical and subtropical conditions. Hormones and behavior, 52(1), pp.26-31. doi.org/10.1016/j.yhbeh.2007.03.026 
Hansen, P.J. (2009). Effects of heat stress on mammalian reproduction. Philosophical transactions of the Royal Society of London. Series B, Biological sciences, 364(1534), pp.3341-3350. doi.org/10.1098/rstb.2009.0131

Ibanescu, I., Siuda, M., \& Bollwein, H. (2020). Motile sperm subpopulations in bull semen using different clustering approaches - Associations with flow cytometric sperm characteristics and fertility. Animal Reproduction Science, 215, 106329. doi. org/10.1016/j.anireprosci.2020.106329

Jiménez-Severiano, H. (2002). Sexual development of dairy bulls in the Mexican tropics. Theriogenology, 58(5), pp.921-932. doi. org/10.1016/S0093-691X(02)00930-5

Khan, I. M., Khan, R. U., Qureshi, M. S., Usman, T., Khan, A., Ullah, Z., \& Rehman, H. (2018). Cross breeding promotes deterioration of semen quality in cattle bulls. Pakistan Journal of Zoology, 50(1), pp.97-103. doi.org/10.17582/JOURNAL. PJZ/2018.50.1.97.103

Menegassi, S.R.O., Barcellos, J.O.J., Peripolli, V., Dias, E.A., Costa Junior, J.B.G., Vieira, M.D.M., \& Moojen, F.G. (2015). Reproductive success or failure in four breed groups of beef bulls. Revista Brasileira de Zootecnia, 44(7), pp.240-247. doi.org/10.1590/ S1806-92902015000700002

Morrell, J.M. (2020). Heat stress and bull fertility. Theriogenology, 153, pp.62-67. doi.org/10.1016/j.theriogenology.2020.05.014

Nienaber, J.A., \& Hahn, G.L. (2007). Livestock production system management responses to thermal challenges. International Journal of Biometeorology, 52(2), pp.149-157.

Rahman, M.B., Schellander, K., Luceño, N.L., \& Van Soom, A. (2018). Heat stress responses in spermatozoa: Mechanisms and consequences for cattle fertility. Theriogenology, 113, pp. 102-112.doi.org/10.1016/j.theriogenology.2018.02.012

Sitienei, I., Gillespie, J., \& Scaglia, G. (2018). Adoption of management practices and breed types by US grass-fed beef producers. The Professional Animal Scientist, 34(6), pp.571-580. doi.org/10.15232/pas.2018-01711

Torres-Aburto, V.F., Barrientos-Morales, M., Hernández-Flores, H., Rodríguez-Andrade, A., Cervantes-Acosta, P., Landi, V., Domínguez-Mancera, B. (2020a). Breeding soundness examination and herd proficiency of local genetic groups of bulls in tropical environment conditions in Veracruz, Mexico. Italian Journal of Animal Science, 19(1), pp.840-855. doi.org/10. 1080/1828051X.2020.1803773

Torres-Aburto, V. F., Domínguez-Mancera, B., Vazquez-Luna, D., \& Espinosa Ortiz, V. E. (2020b). Costo del intervalo interparto en la producción bovina tropical del sureste de México. AgroProductividad, 13(7), pp. 45-51. doi.org/10.32854/agrop.vi.1651 